\title{
Antioxidant defenses in diabetes mellitus: a clinical and molecular approach
}

\author{
Carlos Kusano Bucalen Ferrari* \\ Institute of Biological and Health Sciences (ICBS), Campus Universitário do Araguaia, Federal University of Mato Grosso (UFMT), Brazil
}

\begin{abstract}
Oxidative and nitrosative stress reactions are implicated in cell and organ damage due to diabetes mellitus. In both type 1 and type 2 DM there is a massive oxidative and nitrosative stresses which have been associated with intensive changes on both antioxidant enzyme systems (SOD, CAT, GPx, GSH) and total antioxidant capacity (TAC) causing peroxidative damage to lipids, proteins, nucleic acids and carbohydrates which can be used as DM biomarkers. Molecular pathophysiology of diabetes mellitus envolves induction of the the NFkB and p38-MAPK cell signaling pathways by Rac, TNF- $\alpha$, TLR4, decrease of antioxidant defenses, and direct mitochondrial damage. Knowledge of molecular pathways is essential for research of newer preventive and therapeutic approaches in diabetes mellitus complications (atherosclerosis, myocardial damage, endothelial dysfunction, and renal failure).
\end{abstract}

\section{Introduction}

When oxygen, nitrogen or chlorine reactive species are excessively formed in cells and tissues they are implicated in many pathophysiological and disease events, including diabetes mellitus (DM) $[1,2]$. As a consequence of the oxidative and nitrosative stresses occurs lipid peroxidation (measured by biomarkers like malonaldehyde, 4-hydroxynonenal, and conjugated dienes), protein and aminoacid oxidation (evaluated by protein carbonyls), nucleic acid oxidation (quantifyied by DNA oxidized bases) and carbohydrate oxidation (measured by glycosilation products like glycated hemoglobin [HbA1] and advanced glycation end products [AGEs] commonly found in DM animal models and human patients [3-8].

Oxidative and nitrosative stresses are situations characterized when the production of free radicals surpass the antioxidant defense levels, resulting in many peroxidative and nitrosative damaging reactions which in turn cause since DNA injury and mutations until cell death by necrosis or apoptosis [2].

During at least four decades, an extensive number of research groups have been studied the oxidative and nitrosative stress biomarkers as well as the different antioxidant defense mechanisms by measuring the antioxidant enzymes (superoxide dismutase [SOD], catalase, glutathione reductase [GSH], glutathione peroxidase [GPx], ceruloplasmin, metallothioneins) $[1,2,9]$. In DM patients its well established that oxidative and nitrosative stress decreases cell antioxidant enzyme defenses, especially the GSH, and increase the SOD activity in order to detoxify the superoxide anion mitochondrial overload $[7,8,10,11]$. In macrophages of alloxan-induced diabetes, there were higher levels of SOD activity which were further stimulated by melatonin activity, but decreased by insulin action [12].

In the beginning of the 90's, Miller et al. [13], based on techniques from the 1980 decade, had developed a new total antioxidant capacity assay, which was called by "total antioxidant capacity" (TAC). The advantage of this assay is to measure the antioxidant capacity of virtually all elements and compounds of a biological sample (blood, urine, feces, tissue sample), vegetable or fruit extract or even foods or pharmaceuticals [14-16].

This article review and update the clinical, cellular, and molecular knowledge of free radicals and antioxidant defenses in diabetes mellitus.

\section{Ethiopathogenesis of diabetes mellitus I and II}

Diabetes mellitus has been conceptualized as a group of metabolic disorders characterized by hyperglicemia as a result of insulin secretion failure and/or lacking of insulin action on target cells. The chronic diabetic hyperglicemic state has been related to long-term organ damage especially to the heart, endothelium and blood vessels, nerves, kidney, and eyes [17-19].

\section{Type I diabetes mellitus}

The highly toxic and reactive hydroxyl free radicals are released as a consequence of the pro-inflammatory immunoglobulin-mediated beta cell attack in type I diabetes mellitus (T1DM) patients [20]. In T1DM genetic as well environmental factors induces free radical release by beta cells which in turn activates resident macrophages [21]. Those resident pancreatic macrophages are the primary sources of free radicals in which also participates the recruited and activated macrophages, dendritic cells, and in a later phase the specifically activated T-lymphocytes that decisively contribute to destruction of the insulin secreting $\beta$ cells [21,22]. Free radical release in T1DM patients is triggered by activation of the NFkB pathway and consequently the

Correspondence to: Carlos K B Ferrari, Institute of Biological and Health Sciences (ICBS), Campus Universitário do Araguaia”, Federal University of Mato Grosso (UFMT). Av. Valdon Varjão, 6390, Setor Industrial, Barra do Garças, 78.600-000, MT, Brazil, E-mail: drcarlosferrari.ufmt@gmail.com

Key words: antioxidant capacity, free radicals, nitrosative stress, oxidative stress, diabetes mellitus

Received: September 30, 2017; Accepted: November 17, 2017; Published: November 21, 2017 
induction of TNF- $\alpha$ and IL- $1 \beta$ cytokines from antigen-presenting cells (macrophages and dendritic cells) $[21,22]$.

\section{Type II diabetes mellitus}

As a consequence of glucotoxicity and lipotoxicity there is a chronic loading of oxygen and nitrogen free radicals in type 2 diabetes mellitus patients [20].

In T2DM, although genes are plausible associated with the disease risk, lacking of exercise, obesity, poor dietary habits, poor sleeping, and other risk factors have been implicated in disease causality [22-26].

\section{Is Diabetes mellitus associated with decrease total anti- oxidant capacity?}

It should be emphasized oxidative stress and consequently the depletion of cell antioxidants is not always present in diabetes, since it correlates with disease progression and severity. In an animal model of diabetes, increased lipid peroxidation was observed with no further changes in antioxidant parameters (SOD, ceruloplasmin, GPx, GSH and TAC) [27]. In other experimental model of diabetes authors observed decreased levels of renal catalase despite of increased levels of heart catalase, kidney and heart SOD, and liver GPx [28].

T2DM patients, with or without proteinuria, a biomarker of renal damage, had very lower TAC levels compared with the control group (DM-free) $(1.7 \mathrm{mmol} / \mathrm{L}$ and $1.4 \mathrm{mmol} / \mathrm{L}$ versus $2.7 \mathrm{mmol} / \mathrm{L})$ [3]. In the same manner, it was verifyied a significant impairment of plasma TAC and GSH and an increase of lipid peroxidation in T1DM children patients [5]. Diabetic men had increased values of both lipid peroxidation products and advanced glycoperoxidation end products (AGEs), and reduced TAC in seminal plasma compared to nondiabetic men [29].

Among diabetic patients, obesity has an additional effect on decrement of the TAC, SOD, and vitamin C levels [30].

A study with young adult healthy subjects observed an inverse association between dietary TAC and serum glucose, systolic blood pressure, and free fatty acids [31].

A recent study covering patients with diabetic complications observed a significantly increase on oxidative stress markers as well as the total antioxidant capacity [32].

However, women with gestational diabetes mellitus had lower levels of total antioxidant capacity which was correlated with lower vitamin $\mathrm{E}$ and zinc status [33].

An interventional study with pomegranate juice supplementation decreased LDL oxidation and increased TAC in type 2 diabetes mellitus patients [34].

Another study with type 2 diabetic men revealed higher oxidative stress and both lower TAC and zinc values [35] which were corroborated by other studies in different populations [36-40].

In fact, diabetes mellitus has been associated with disruption of cellular zinc turnover with increased loss of zinc and oxidative stress $[35,41,42]$.

\section{Hyperglycemia as the great villain in diabetes mellitus: induction of massive depletion of antioxidant defenses}

Hyperglycemia induces impairment on functional activity of the pancreatic islet beta cells, an effect which has been associated to an intense and deleterious oxidative stress [43]. While the functionality of beta cells is preserved, the plasma TAC levels remain higher [44]. Prediabetes pathogenesis characterized by insulin resistance and hyperinsulinemia is followed by the failure on glycemic control and finally the diabetic hyperglycemic status [45]. During the DM pathogenesis plasma TAC levels are being progressively reduced [44-48]. It is important to note that patients with acute pancreatitis due to alcoholism, biliary problems, trauma or idiopathic origin had presented yet a $40 \%$ decrease on serum TAC [49]. When the subject becomes diabetic his antioxidant defenses are compromised and this has been correlated with progressive DNA damage [50]. Another study has pointed out that diabetic animals had increased lipid peroxidation than the normal group; and that DNA oxidative damage was higher among those animals with metabolic syndrome features [51]. In this respect, increased oxidative DNA damage is suggested to occur in insulin-resistant prediabetics as well as T2DM patients [52]. Diabetic patients without glycemic control presented reduction on plasma TAC, which was partially recovered among DM patients with adequate glycemic control [46].

An interesting Spanish study evaluated erythrocyte antioxidants from healthy subjects and diabetic patients with or without microvascular complications and found decreased levels of erythrocyte GPX, GSH and increased levels of erythrocyte SOD in both diabetic groups compared to controls [52]. The same study also revealed increased lipid peroxidation and hemoglobin glycation among the diabetic groups, whereas advanced oxidation protein products were higher among those diabetics with microvascular complications. Although TAC can not be affected in well controlled T2DM patients [53], it has been depleted in uncontrolled type 2 DM patients where glycated hemoglobin $\left(\mathrm{HbA}_{1 \mathrm{c}}\right)$ was positively associated with both lipid peroxidation products and c-reactive protein (PCR), whereas $\mathrm{HBA}_{1}$ was inversely associated with SOD and TAC levels [54]. This depletion of intracellular GSH reserves was also observed in the liver and kidney [55]. This depletion can be partially explained by the overexpression of the NADPH oxidase in kidneys and subsequent free radical damage in diabetic nephropathy [56], since impaired function of NADPH oxidase has been suggested to have a central role on activation of other oxidative stress enzymes [57]. It has been found that DNA oxidation and nitrosative stress with excessive production of nitric oxide and peroxynitrite were implicated in progression of chronic diabetic nephropathy [58]. It has been suggested that bilirubin and biliverdin can afford protection against diabetic nephropathy by blocking NADPH oxidase [59].

A recent study reported that DM patients had higher levels of lipid peroxidation products, uric acid, total cholesterol, LDL-cholesterol, and tryglycerides, and lower values of enzymatic antioxidants (SOD and GSH) and of HDL-cholesterol [60], confirming previous studies [61].

A previous study confirmed that diabetic polyneuropathy was linked to a significantly lowering on blood TAC [62]. However, in a recent clinical study, TAC was not significantly decreased even in the presence of SOD and GPX depletion [63]. It is possible that this discrepancy could be due to different clinical stages of the patients from the two studies. Further work is necessary to investigate the possible clinical correlations between antioxidant defense and nervous system commitment in diabetic subjects. Diabetic patients with retinopathy had also increased levels of lipid peroxidation and reduced serum concentrations of SOD, GSH, and vitamin C [64]. In aqueous humor of hyperglycemic animals, it was found decreased levels of TAC, ascorbic acid, and GSH [65], which can contribute to diabetic retinal damage. 


\section{Molecular pathways of diabetes mellitus pathogenesis}

Investigating the molecular shape of diabetes, it has been reported mitochondrial dysfunction and apoptosis of myocardiocytes from diabetic human heart [66]. In this special context, the disruption of the uncoupling mitochondrial protein-2 (UC-2) into the inner membrane has been associated with a phenotype of massive and chronic free radical release [67].

Considering the brain of diabetic rats it has been found impaired thioredoxin response, decreased levels of SOD, and increased levels of GPX [68], confirming previous study in which hyperglycemia had induced inhibition of thioredoxin function by the action of p38-MAPK triggering of thioredoxin-interacting protein (Txnip), causing oxidative stress [69]. In rat experimental model of diabetes, hyperglycemic state had induced Txnip expression which has been implicated with increased inflammation and gliosis [70]. It has been suggested nitric oxide blocks expression of the Txnip improving thioredoxin activity [71].

This mechanism of Txnip inhibition of thioredoxin function associated with increased oxidative stress has also been demonstrated in glucose-exposed endothelial cells [72]. In the same manner, the inflammatory cytokine tumor necrosis factor- $\alpha$ (TNF- $\alpha$ ) promotes insulin resistance through p38-MAPK pathway [73]. Beyond higher levels of TNF- $\alpha$, other important inflammatory mediators (C-reactive protein and interleukins 6 and 8) were also increased among gestational diabetes mellitus patients [74]. TNF- $\alpha$ also causes activation of $\mathrm{NFkB}$ which mediates cell signaling through IKK-b inducing insulin resistance and coronary arteriolar dysfunction [75]. NFKB activation triggers potent inflammatory reactions found in acute pancreatitis, $\mathrm{DM}$, metabolic syndrome, brain injury, Alzheimer's disease, and diabetic nephropathy [76]. Into the cortex of the kidneys, NFkB activation was associated with increased expression of plasminogen activator inhibitor-1 (PAI-1) and enhanced expression of the intercellular adhesion molecule-1 (ICAM-1) which were associated with higher degree of renal inflammation in diabetic rats [77]. The activation of $\mathrm{p} 38$-MAPK pathway also impairs insulin action into the myocardium increasing free radical-mediated infarction [78]. Diabetic mice with abbrogated gene expression of the p38-MAPK had decreased levels of free radical production as well as lower degree of myocardial damage and apoptosis compared with normal gene expression mice [79]. Cardiomyocytes were protected against oxidative stress-induced hyperglycemic toxicity through inhibition of the p38-MAPK signaling pathway [80].

Another downregulator of the Txnip is represented by activation of the AMP-activated protein kinase (AMPK) which stimulates forkhead transcription factor 3 (FOXO3) inhibiting reactive oxygen species production [81]. This mechanism of AMPK activation has also been suggested to protect kidney tissues from diabetic rats [82].

In the same context, beta cells can adapt against free radical damage by expressing the nuclear-factor E2-related factor (Nrf-2) which triggers the expression of many different antioxidant genes, helping to rescue beta cells from the genotoxic free radical insults [67]. The Nrf2 induction leads to expression of antioxidant genes and attenuation of the NFkB inflammatory pathway protecting endothelium, the nephron, and other structures against hyperglicemic-load induced toxicity [83-86].

Other molecular regulator of free radical release in diabetes mellitus is represented by Rac proteins (Rac1-ubiquitously expressed, Rac2restricted to hematopoietic tissues, and Rac3-restricted to the central nervous system). These proteins are small Rho GTPases (Rac1, Rac2 and Rac3) which can provoke endoplasmic reticulum stress and induce mitochondrial ROS production via NFkB and Akt signaling mechanisms [87]. This endoplasmic reticulum stress is mediated by NFKB, JNK, and p38MAPK pathways and operates the endothelial dysfunction in diabetes mellitus patients [88]. Another pathway of endothelial dysfunction in DM is represented by hyperhomocysteinemia, an independent risk factor for both cardiovascular and cerebrovascular diseases $[89,90]$. Excessive blood homocysteine has been implicated in massive oxidative stress and decreased plasma total antioxidant capacity which could be reversed by both antioxidant and L-arginine supplementation [91,92]. Hyperhomocysteinemia, a common feature in diabetes mellitus, has been associated with increased cardiovascular disease risk and polyneuropathy in DM patients [93-95].

In diabetic cardiomyopathy, hyperglycemia causes activation of Racl signaling disturbing endoplasmic reticulum and mitochondria resulting in free radical overload and myocardium cell death $[96,97]$. Under excessive levels of glucose, Racl activation induced expression of a cell surface lipid transporter, the CD36, which triggers mitochondrial dysfunction, oxidative stress and apoptosis of beta cells [98]. In the same study, inhibition of Racl abrogated the deleterious effects of high glucose on pancreatic beta cells. In fact, inhibition of Racl was associated with abrogation of membrane NADPH oxidase activity and suppression of free radical production $[87,99]$.

Hyperglycemia also triggers activation of the Toll-like receptors- 4 (TLR4) in myocardiocytes membrane, a cell surface receptor responsible for pathogen recognition by the immune cells [100]. In this study, the inhibition of TLR4 blocks apoptosis, NADPH oxidase activity and free radical release in cardiomyocytes. The same mechanism is responsible for doxorubicin-induced myocardium toxicity [101]. Another study also demonstrated that blocking TLR4 signaling also rescue neuronal survival in diabetic rats [102]. Chronic triggering of TLR4 pathway induces both insulin resistance and amyloid beta deposition [103]. It has been suggested that TLR4 action is mediated by NFkB signaling pathway [104]. These complex prodiabetic and antidiabetic molecular mechanisms are represented in Figure 1.

Other important proteins involved in oxidative stress and mitochondrial dysfunction in diabetic experimental models include frataxin, duodenal homeobox factor-1 (PDX-1), MafA, and forkhead box protein O1 (FOXO1) [41].

Some important classic laboratory features of diabetes mellitus (hypercholesterolemia, hypertrygliceridemia, glycemia, arterial blood pressure, billirrubin, insulin resistance, creatinine, and C-reactive protein) are inversely associated with TAC, suggesting increased risk of atherothrombosis [105-109]. The unique DM biomarker that is positively associated with total antioxidant capacity is the uric acid $[110,111]$, which has also been positively associated with DM risk and prognosis [111,112]. Increased uric acid levels have been pointed out to be the possible explanation for increased TAC levels in diabetic patients in some studies [32].

Total antioxidant capacity has a potential to be a diabetes diagnostics and therapeutics biomarker since it has been found to be normal or increased in controlled T2DM patients and reduced in uncontrolled and complicated T2DM subjects [44-48,53,54,62,65,113].

However, laboratorial evaluation of antioxidant capacity in diabetic patients should include the total antioxidant capacity test and other biochemical analysis listed in Table 1 . 
Table 1. Laboratory examination of antioxidant-oxidant balance in diabetic patients.

\begin{tabular}{|l|l|l|}
\hline Test & Use/samples & Comment \\
\hline Total Antioxidant Capacity (TAC) & Cells, tissues, blood, saliva, and urine & Should be controlled regarding physiological changes \\
\hline Superoxide dismutase (SOD) & Same. It indicates oxidation & Should be measured at different time intervals \\
\hline Catalase (CAT) & Same. It indicates antioxidant defense & Should be measured at different time intervals \\
\hline Lipid peroxides & Same. The first products of lipid peroxidation & Indicates only the inicial phase of lipid peroxidation \\
\hline Conjugate dienes & Same. The first products of lipid peroxidation & Same as above. \\
\hline Malonaldehyde & Same. The final product of lipid peroxidation. & Could react with other compounds, yielding false results \\
\hline Glutathione (GSH) and Glutathione Peroxidase (GPX) & Same. Indicate cell antioxidant defense & \\
\hline Glycated Hemoglobin (HBA1C) & Blood & Specific marker of oxidation in diabetic patients \\
\hline
\end{tabular}

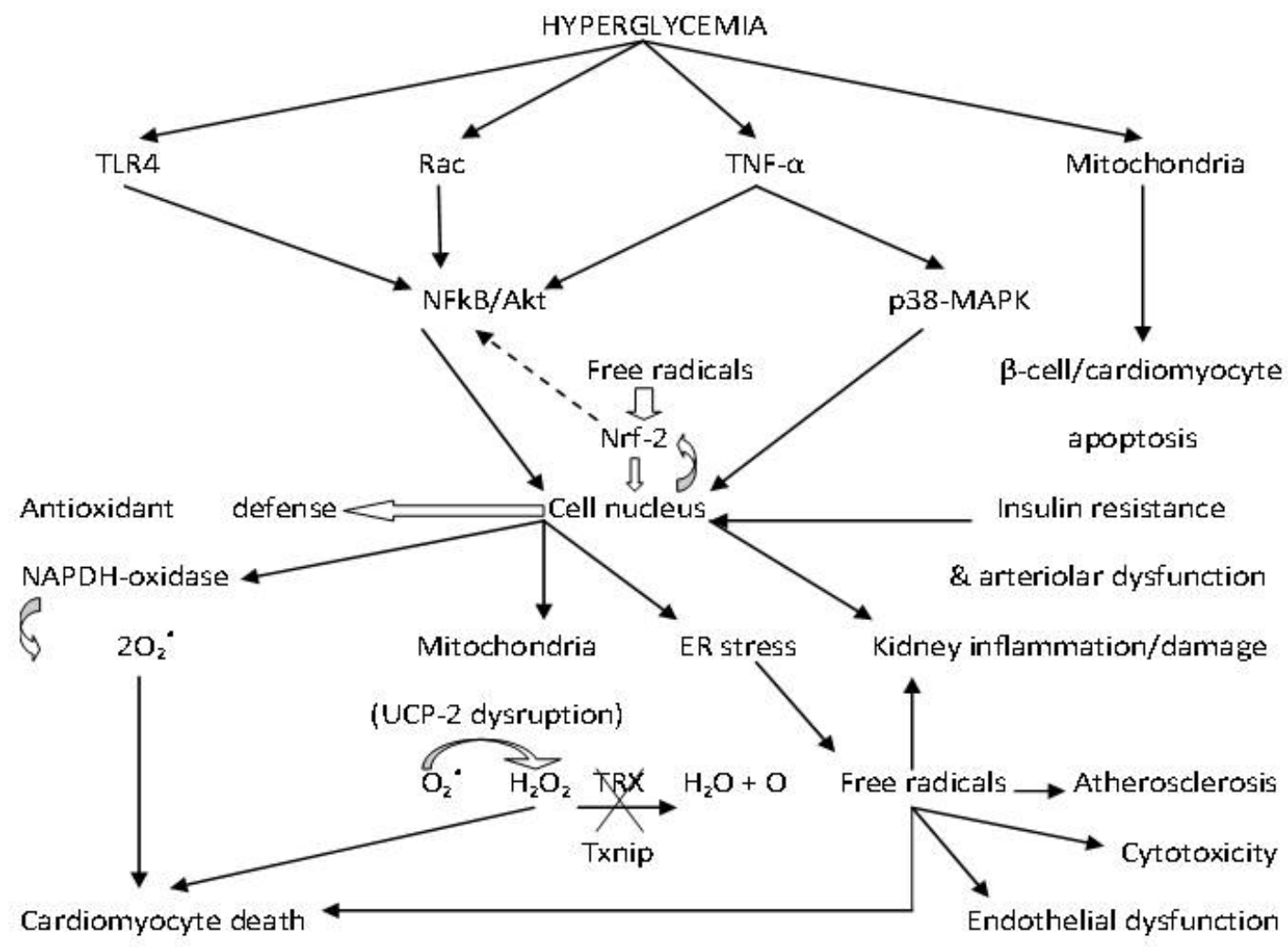

$x$ or $-\rightarrow=$ blocking

activation

Figure 1. Molecular roles of hyperglycemia in diabetes mellitus-induced pathophysiology.

Drinking of sulphurous water could decrease oxidative stress and improve the glycemic values in diabetes mellitus [114].

Beyond impairment of the antioxidant defenses, DM causes molecular dysfunctions that can be targeted for development of newer therapeutic and preventive strategies like dietary intake of antioxidantrich foods and exercise training [14,115-124].

\section{References}

1. Vladimirov YA, Proskurnina EV (2009) Free radicals and cell chemiluminescence. Biochemistry (Mosc) 74: 1545-1566. [Crossref]

2. Ferrari CKB, França EL, Honorio-França AC (2009) Nitric oxide, health and disease. $J$ Appl Biomed 7: 163-173.

3. Opara EC, Abdel-Rahman E, Soliman S, Kamel WA, Souka S, et al. (1999) Depletion of total antioxidant capacity in type 2 diabetes. Metabolism 48: 1414-1417. [Crossref]
4. Ferrari CKB (2001) Oxidative stress pathophysiology: searching for an effective antioxidant protection. Int Med $J$ 8: 175-184.

5. Varvarovská J, Racek J, Stozický F, Soucek J, Trefil L, et al. (2003) Parameters of oxidative stress in children with Type 1 diabetes mellitus and their relatives. J Diabetes Complications 17: 7-10. [Crossref]

6. Qujeq D, Habibinudeh M, Daylmkatoli H, Rezvani T (2005) Malondialdehyde and carbonyl contents in the erythrocytes of streptozotocin-induced diabetic rats. Int $\mathrm{J}$ Diabet Metabol 13: 96-98.

7. Nweke I, Ohaeri OC, Ezeala C (2009) Effect of vitamin on malondialdehyde and glutathione levels in type 2 diabetic Nigerians. Internet J Nutr Well.

8. Hanachi P, Moghadam RH, Latiffah AL (2009) Investigation of lipid profiles and lipid peroxidation in patients with type 2 diabetes. Eur J Sci Res 28: 6-13.

9. Gutteridge JM, Halliwell B (2010) Antioxidants: Molecules, medicines, and myths Biochem Biophys Res Commun 393: 561-564. [Crossref] 
10. Moussa SA (2008) Oxidative stress in diabetes mellitus. Rom J Biophys 18: 225-236.

11. Mahboob M, Rahman MF, Grover P (2005) Serum lipid peroxidation and antioxidant enzyme levels in male and female diabetic patients. Singapore Med J 46: 322-324.

12. França EL, Feliciano ND, Silva KA, Ferrari CKB, Honorio-França AC (2009) Modulatory role of melatonin on superoxide release by spleen macrophages isolated from alloxan-induced diabetic rats. Bratisl Med J 110: 517-522.

13. Miller NJ, Rice-Evans C, Davies MJ, Gopinathan V, Milner A (1993) A novel method for measuring antioxidant capacity and its application to monitoring the antioxidant status in premature neonates. Clin Sci 84: 407-412. [Crossref]

14. Ferrari CKB (2008) Total antioxidant capacity: a biomarker in biomedical and nutritional studies. J Cell Mol Biol 7: 1-15.

15. Percario S, Naufal AS, Gennari MS, Gennari JL (2009) Antioxidant activity of edible blushing Wood mushroom, Agaricus silvaticus Schaeff. (Agaricomicetideae) in vitro. Int J Med Mushr 11: 133-139.

16. Percario S (2010) Prevention of oxidative stress in renal ischemia-reperfusion syndrome in rats with nutritional antioxidant supplementation. Rev Nutr 23: 259-267.

17. ADA (2010) Diagnosis and classification of diabetes mellitus. Diabet Care 33: S62-S69. [Crossref]

18. Zieleniak A, Cypryk K, Wozniak LA, Bienkiewicz M, Wójcik M (2012) Adenosine receptors expression is elevated in leukocytes of gestational diabetes mellitus (GDM) subjects - a preliminary study. Endokrynol Polska 63: 110-114. [Crossref]

19. Radenkovic SP, Kocic RD, Pešic MM, Dimic DN, Golubovic MDV, et al. (2011) The hypertriglyceridemic waist phenotype and metabolic syndrome by differing criteria in type 2 diabetic patients and their relation to lipids and blood glucose control. Endokrynol Polska 62: 316-323. [Crossref]

20. Taheri N, Iraj B, Amini M, Amini P, Aminorroya A (2010) Cardiovascular risk factors in relatives of type 2 diabetics with normal glucose tolerance test and elevated one-hour plasma glucose. Endokrynol Polska 61: 359-363. [Crossref]

21. Lenzen S (2008) Oxidative stress: the vulnerable beta-cell. Biochem Soc Trans 36: 343-347. [Crossref]

22. Delmastro MM, Piganelli JD (2011) Oxidative stress and redox modulation potential in type I diabetes mellitus. Clin Devel Immunol. [Crossref]

23. Gregg EW, Gerzoff RB, Caspersen CJ, Williamson DF, Narayan KMV (2003) Relationship of walking to mortality among US adults with diabetes. Arch Intern Med 163: 1440-1447. [Crossref]

24. Hu FB, Li TY, Colditz GA, Willett WC, Manson JE (2003) Television watching and other sedentary behaviors in relation to risk of obesity and type 2 diabetes mellitus in women. JAMA 289: 1785-1791. [Crossref]

25. Nicklas BJ, You T, Pahor M (2005) Behavioural treatments for chronic systemic inflammation: effects of dietary weight loss and exercise training. CMAJ 172: 11991209. [Crossref]

26. Ferrari CKB (2008) Metabolic syndrome and Obesity: epidemiology and prevention by physical activity and exercise. J Exerc Sci Fitness 6: 87-96.

27. Ferrari CKB, Guimarães CF, Honorio-França AC, França EL (2011) Health and quality of life among workers from a greater food supplier company in Sao Paulo (SP), Brazil. Middle-East J Scient Res 7: 543-549.

28. Inoue H, Murakami H, Matsumoto M, Kaji Y (2011) Oxidative and anti-oxidative status in blood of streptozotocin-induced diabetic piglets. Asian-Austral J Anim Sci 24: 818-824.

29. Strother RM, Thomas TG, Otsyula M, Sanders RA, Watkins JB 3rd (2001) Characterization of oxidative stress in various tissues of diabetic and galactose-fed rats. Int J Exp Diabetes Res 2: 211-216. [Crossref]

30. Karimi J, Goodarzi MT, Tavilani H, Khodadadi I, Amiri I (2011) Relationship between advanced glycation end products and increase lipid peroxidation in semen of diabetic men. Diabet Res Clin Pract 91: 61-66. [Crossref]

31. Dambal SS, Indumati V, Kumari S (2011) Role of oxidative stress in obesity with an insight into type II diabetes mellitus. J Clin Diagn Res 5: 52-54.

32. Pieme CA, Tatangmo JA, Simo G, Nya PCB, Moor VJA, et al. (2017) Relationship between hyperglycemia, antioxidant capacity and some enzymatic and non-enzymatic antioxidants in African patients with type 2 diabetes. BMC Res Notes 10: 141. [Crossref]

33. Parast VM, Paknahad Z (2017) Antioxidant Status and Risk of Gestational Diabetes Mellitus: a Case-Control Study. Clin Nutr Res 6: 81-88. [Crossref]
34. Sohrab G, Ebrahimof S, Sotoudeh G, Neyestani TR, Angooran P, et al. (2017) Effects of pomegranate juice consumption on oxidative stress in patients with type 2 diabetes: a single-blind, randomized clinical trial. Int J Food Sci Nutr 68: 249-255. [Crossref]

35. Mahmood AR (2016) Estimation of oxidative stress and some trace elements in Iraqi men patients with type 2 diabetes mellitus. Iraqi J Pharm Sci 25: 17-22.

36. Tangvarasittichai S, Poonsub P, Tangvarasittichai O, Sirigulsatien V (2009) Serum levels of malondialdehyde in type 2 diabetes mellitus Thai subjects. Siriraj Med J 61: 20-23.

37. Eldin EEMN, Almarzouki A, Assiri AM, Elsheikh OM, Mohamed BEA, et al. (2014) Oxidized low density lipoprotein and total antioxidant capacity in type-2 diabetic and impaired glucose tolerance Saudi men. Diabetol Metab Syndr 6: 94. [Crossref]

38. Dasegowda SM, Jeppu AK, Sushith KAK (2015) Serum adenosine deaminase as oxidative stress marker in type 2 diabetes mellitus. Int J Res Med Sci 3: 1195-1198.

39. Sharma M, Gupta S, Singh K, Mehndiratta M, Gautam A, et al. (2016) Association of glutathione-S-transferase with patients of type 2 diabetes mellitus with and without nephropathy. Diabet Metab Syndr 10: 194-197. [Crossref]

40. Ganjifrockwala FA, Joseph JT, George G (2017) Decreased total antioxidant levels and increased oxidative stress in South African type 2 diabetes mellitus patients. $J$ Endocrinol Metab Diabet South Africa 22: 21-25.

41. Gerber PA, Rutter GA (2017) The Role of Oxidative Stress and Hypoxia in Pancreatic Beta-Cell Dysfunction in Diabetes Mellitus. Antioxid Redox Signal 26: 501-518. [Crossref]

42. Gu Y, Lian X, Sun W, Gao B, Fu Y (2017) Diabetes mellitus induces alterations in metallothionein protein expression and metal levels in the testis and liver. $J$ Int Med Res. [Crossref]

43. Puchau B, Zulet MA, Echávarri AG de, Hermsdorff HHM, Martínez JA (2010) Dietary total antioxidant capacity is negatively associated with some metabolic syndrome features in healthy young adults. Nutrition 26: 534-541. [Crossref]

44. Miyazaki Y, Kawano H, Yoshida T, Miyamoto S, Hokamaki J, et al. (2007) Pancreatic B-cell function is altered by oxidative stress induced by acute hyperglycemia. Diabet Med 24: 154-160. [Crossref]

45. Song F, Jia W, Yao Y, Hu Y, Lei L, Lin J, et al. (2007) Oxidative stress, antioxidan status, and DNA damage in patients with impaired glucose regulation and newly diagnosed type 2 diabetes mellitus. Clin Sci 112: 599-606. [Crossref]

46. Ferrari CKB (2007) Pathophysiology and Clinics of Metabolic Syndrome. Arq Catarin Med 36: 90-95. [Crossref]

47. Rysz J, Baszczak R, Banach M, Kedziora-Kornatowska K, Kornatowski T, et al. (2007) Evaluation of selected parameters of the antioxidative system in patients with type 2 diabetes in different periods of metabolic compensation. Arch Immunol Ther Exp (Warsz) 55: 335-340. [Crossref]

48. Wang Z, Li L, Zheng FP, Jia CF, Ruan Y, et al. (2011) Correlation between the amplitude of glucose excursion and the oxidative/antioxidative system in subjects with different types of glucose regulation. Biomed Environ Sci 24: 68-73. [Crossref]

49. Kaur S, Verma I, Narang APS, Chinna RS, Singh P, et al. (2011) Assessment of total antioxidant status in acute pancreatitis and prognostic significance. Int J Biol Med Res 2: $575-576$

50. Jain N, Naseem I, Ahmad J (2009) Evaluation of DNA damage and metabolic syndrome parameters in diabetic rabbits supplemented with antioxidants. Fund Clin Pharmacol 23: 197-205.

51. Al-Aubaidy HA, Jelinek HF (2011) Oxidative DNA damage and obesity in type 2 diabetes mellitus. Eur J Endocrinol 164: 899-904. [Crossref]

52. Martín-Gallán P, Carrascosa A, Gussinyé M, Domínguez C (2003) Biomarkers of diabetes-associated oxidative stress and antioxidant status in young diabetic patients with or without subclinical complications. Free Rad Biol Med 34: 1563-1574.

53. Savu O, Ionescu-Tirgoviste C, Atanasiu V, Gaman L, Papacocea R, et al. (2012) Increase in total antioxidant capacity of plasma despite high levels of oxidative stress in uncomplicated type 2 diabetes mellitus. J Intern Med Res 40: 709-712.

54. Bigagli E, Raimondi L, Mannucci E, Colombi C, Bardini G, et al. (2012) Lipid and protein oxidation products, antioxidant status and vascular complications in poorly controlled type 2 diabetes. Brit J Diabet Vasc Dis 12: 33-39.

55. Winiarska K, Malinska D, Szymanski K, Dudziak M, Bryla J (2008) Lipoic acid ameliorates oxidative stress and renal injury in alloxan diabetic rabbits. Biochimie 90 : 450-459. 
56. Takayanagi R, Inoguchi T, Ohnaka K (2011) Clinical and experimental evidence for oxidative stress as an exacerbating factor in diabetes mellitus. J Clin Biochem Nutr 48:72-7.

57. Schramm A, Matusik P, Osmenda G, Guzik TJ (2012) Targeting NADPH oxidases in vascular pharmacology. Vascul Pharmacol 56: 216-231. [Crossref]

58. Fujii H, Kono K, Nakai K, Goto S, Komaba H, et al. (2010) Oxidative and nitrosative stress and progression of diabetic nephropathy in type 2 diabetes. Am J Nephrol 31: 342-352.

59. Fujii M, Inoguchi T, Sasaki S, Maeda Y, Zheng J, et al. (2010) Bilirubin and biliverdin protect rodents against diabetic nephropathy by downregulating $\mathrm{NAD}(\mathrm{P}) \mathrm{H}$ oxidase. Kidney Intern 78: 905-919.

60. Al-Rawi NH (2011) Oxidative stress, antioxidant status and lipid profile in the saliva of type 2 diabetics. Diab Vasc Dis Res 8: 22-28. [Crossref]

61. Rizvi SI, Srivastava N (2009) Oxidative stress in first degree relatives of type 2 diabetic patients. Int J Diabet Metabol 17: 17-19.

62. Sofic E, Rustembegovic A, Kroyer G, Cao G (2002) Serum antioxidant capacity in neurological, psychiatric, renal diseases and cardiomiopathy. J Neural Transm 109: 711-719.

63. Kasznicki J, Kosmalski M, Sliwinska A, Mrowicka M, Stanczyk M, et al. (2012) Evaluation of oxidative stress markers in pathogenesis of diabetic neuropathy. Mol Biol Rep 39: 8669-8678. [Crossref]

64. Samuel TV, Murthy DSJ, Dattatreya K, Babu PS, Johncy SS (2010) Impaired antioxidant defense mechanism in diabetic retinopathy. J Clin Diagn Res 4: 3430-3436.

65. Gumieniczek A, Owczarek B, Pawlikowska B (2012) Oxidative/nitrosative stress and protein damages in aqueous humor of hyperglycemic rabbits: effects of two oral antidiabetics, pioglitazone and repaglinide. Exp Diabet Res.

66. Anderson EJ, Rodriguez E, Anderson CA, Thayne K, Chitwood WR, et al. (2011) Increased propensity for cell death in diabetic human heart is mediated by mitochondrialdependent pathways. Am J Physiol- Heart Circul Physiol 300: H118-H124.

67. Pi J, Zhang Q, Fu J, Woods CG, Hou Y, et al. (2010) ROS signaling, oxidative stress and Nrf2 in pancreatic beta-cell function. Toxicol Appl Pharmacol 244: 77-83. [Crossref]

68. Lappalainen Z, Lappalainen J, Oksala NK, Laaksonen DE, Khanna S, et al. (2009) Diabetes impairs exercise training-associated thioredoxin response and glutathione status in rat brain. $J$ Appl Physiol 106: 461-467.

69. Schulze PC, Yoshioka J, Takahashi T, He Z, King GL, et al. (2004) Hyperglycemia promotes oxidative stress through inhibition of thioredoxin function by thioredoxininteracting protein. $J$ Biol Chem 279: 30369-30374.

70. Devi TS, Lee I, Hüttemann M, Kumar A, Nantwi KD, et al. (2012) TXNIP links innate host defense mechanisms to oxidative stress and inflammation in retinal Muller glia under chronic hyperglycemia: implications for diabetic retinopathy. Exp Diabet Res.

71. Schulze PC, Liu H, Choe E, Yoshioka J, Shalev A, et al. (2006) Nitric oxide-dependent suppression of thioredoxin-interacting protein expression enhances thioredoxin activity. Arterioscler Thromb Vasc Biol 26: 2666-2672.

72. Li X, Rong Y, Zhang M, Wang XL, LeMaire SA, et al. (2009) Up-regulation of thioredoxin interacting protein (Txnip) by $\mathrm{p} 38$ MAPK and FOXO1 contributes to the impaired thioredoxin activity and increased ROS in glucose-treated endothelial cells. Biochem Biophys Res Commun 381: 660-665.

73. Li G, Barrett EJ, Barrett MO, Cao W, Liu Z (2007) Tumor necrosis factor-a induces insulin resistance in endothelial cells via a p38 mitogen-activated protein kinasedependent pathway. Endocrinol 148: 3356-3363.

74. Zhang J, Chi H, Xiao H, Tian X, Wang Y, et al. (2017) Interleukin 6 (IL-6) and tumor necrosis factor a (TNF-a) single nucleotide polymorphisms (SNPs), inflammation and metabolism in gestational diabetes mellitus in inner Mongolia. Med Sci Monit 23: 4149-4157.

75. Yang J, Park Y, Zhang H, Xu X, Laine GA, et al. (2009) Feed-forward signaling of TNF-a and NF-kB via IKK- $\beta$ pathway contributes to insulin resistance and coronary arteriolar dysfunction in type 2 diabetic mice. Am J Physiol-Heart Circul Physiol 296: H1850-H1858.

76. Paniago EN, Ferrari CKB (2011) Revisiting the pathology of the nuclear factor kappa beta. Int J Biol Chem 5: 291-299.

77. Chen L, Zhang J, Zhang Y, Wang Y, Wang B (2008) Improvement of inflammatory responses associated with NF-kB pathway in kidneys from diabetic rats. Inflamm Res 57: 199-204.
78. Chai W, Wu Y, Li G, Cao W, Yang Z, et al. (2008) Activation of p38 mitogen-activated protein kinase abolishes insulin-mediated myocardial protection against ischemiareperfusion injury. Am J Physiol- Endocrinol Metabol 294: E183-E189.

79. Thandavarayan RA, Watanabe K, Ma M, Gurusamy N, Veeraveedu PT, et al. (2009) Dominant-negative p38a mitogen-activated protein kinase prevents cardiac apoptosis and remodeling after streptozotocin-induced diabetes mellitus. Am J Physiol- Heart Circul Physiol 297: H911-H919.

80. Lei Y, Xu Q, Zeng B, Zhang W, Zhen Y, et al. (2017) Angiotensin-(1-7) protects cardiomyocytes against high glucose-induced injuries through inhibiting reactive oxygen species-activated leptin-p38 mitogen-activated protein kinase/extracellula signal-regulated protein kinase $1 / 2$ pathways, but not the leptin-c-Jun $\mathrm{N}$-terminal kinase pathway in vitro. J Diabet Inv 8: 434-445.

81. Li XN, Song J, Zhang L, LeMaire SA, Hou X, et al. (2009) Activation of the AMPKFOXO3 pathway reduces fatty acid-induced increase in intracellular reactive oxygen species by upregulating thioredoxin. Diabetes 58: 2246-2257. [Crossref]

82. Chang C-C, Chang C-Y, Wu Y-T, Huang J-P, Yen T-H, et al. (2011) Resveratrol retards progression of diabetic nephropathy through modulations of oxidative stress, proinflammatory cytokines, and AMP-activated protein kinase. J Biomed Sci 18: 47.

83. Li W, Khor TO, Xu C, Shen G, Jeong WS, et al. (2008) Activation of Nrf2-antioxidant signaling attenuates NFkappaB-inflammatory response and elicit apoptosis. Biochem Pharmacol 76: 1485-1489.

84. Vaziri ND (2012) Protective effect of Nrf2 and catalase in maternal diabetes-induced perinatal hypertension and kidney disease. Diabetes 61: 2400-2402.

85. Unqvari Z, Bailey-Downs L, Gautam T, Jimenez R, Losonczy G, et al. (2011) Adaptative induction of NF-E2-related factor-2-driven antioxidant genes in endothelial cells in response to hyperglycemia. Am J Physiol-Heart Circul Physiol 300: H1133-H1140.

86. Nimnual AS, Taylor LJ, Nyako M, Jeng HH, Bar-Sagi D (2010) Perturbation of cytoskeleton dynamics by the opposing effects of Rac1 and Rac1b. Small GTPases 1: 89-97. [Crossref]

87. Basha B, Samuel SM, Triggle CR, Ding H (2012) Endothelial dysfunction in diabetes mellitus: possible involvement of endoplasmic reticulum stress? Exp Diabet Res.

88. Durand P, Prost M, Loreau N, Lussier-Cacan S, Blacke D (2001) Impaired homocysteine metabolism and atherothrombotic disease. Lab Invest 81: 645-672.

89. Moat SJ, Lang D, McDowell IF, Clarke ZL, Madhavan AK, et al. (2004) Folate, homocysteine, endothelial function and cardiovascular disease. J Nutr Biochem 15 : 64-79.

90. Malinowska J, Babicz K, Olas B, Stochmal A, Oleszek W (2012) Aronia melanocarpa extract suppresses the biotoxicity of homocysteine and its metabolite on the hemostatic activity of fibrinogen and plasma. Nutrition 28: 793-798.

91. Jablecka A, Bogdanski P, Balcer N, Cieslewicz A, Skoluda A, et al. (2012) The effect of oral L-arginine supplementation on fasting glucose, $\mathrm{HbA} 1 \mathrm{c}$, nitric oxide and tota antioxidant status in diabetic patients with atherosclerotic peripheral arterial disease of lower extremities. Eur Rev Med Pharmacol Sci 16: 342-350.

92. Ebesunun MO, Obajobi EO (2012) Elevated plasma homocysteine in type 2 diabetes mellitus: a risk factor for cardiovascular diseases. Pan Afr Med J 12: 48. [Crossref]

93. Tousoulis D, Kampoli A-M, Stefanadis C (2012) Diabetes mellitus and vascular endothelial dysfunction: current perspectives. Curr Vasc Pharmacol 10: 19-32.

94. González R, Pedro T, Martinez-Hervas S, Civera M, Priego MA, et al. (2012) Plasma homocysteine levels are independently associated with the severity of periphera polyneuropathy in type 2 diabetic subjects. J Peripher Nerv Syst 17: 191-196.

95. Shen E, Li Y, Li Y, Shan L, Zhu H, et al. (2009) Rac1 is required for cardiomyocyte apoptosis during hyperglycemia. Diabetes 58: 2386-2395. [Crossref]

96. Li J, Zhu H, Shen E, Wan L, Arnold JMO, et al. (2010) Deficiency of Rac1 block NADPH oxidase activation, inhibits endoplasmic reticulum stress, and reduce myocardial remodeling in a mouse model of type1 diabetes. Diabetes 59: 2033-2042.

97. Zhang Y, Peng T, Zhu H, Zheng X, Zhang X, et al. (2010) Prevention of hyperglycemiainduced myocardial apoptosis by gene silencing of Toll-like receptor-4. $J$ Transl Med 8: 133

98. Elumalai S, Karunakaran U, Lee IK, Moon JS, Won KC (2017) Rac1-NADPH oxidase signaling promotes CD36 activation under glucotoxic conditions in pancreatic beta cells. Redox Biol 11: 126-134.

99. Riad A, Bien S, Gratz M, Escher F, Westermann D, et al. (2008) Toll-like receptor-4 deficiency attenuates doxorubicin-induced cardiomyopathy in mice. Eur J Heart Fail 10: $233-243$. 
100. Chao W (2009) Toll-like receptor signaling: a critical modulator of cell survival and ischemic injury in the heart. Am J Physiol Heart Circ Physiol 296: H1-12. [Crossref]

101. Chang YJ, Song KE, Park WH, Choi YS, Lee NH (1999) The total antioxidant capacity according to diet and life style in patients with chronic cardiovascular disease. Korean J Clin Pathol 19: 504-509.

102. Li C, Ji T-F, Yu J-L (2017) Effects of the TLR4 signaling pathway on apoptosis of neuronal cells in diabetes mellitus complicated with cerebral infarction in a rat model. Sci Rep 7: 43834.

103. Huang NQ, Jin H, Zhou SY, Shi JS, Jin F (2017) TLR4 is a link between diabetes and Alzheimer's disease. Behav Brain Res 316: 234-244. [Crossref]

104. Ferrari CK (2007) Functional foods and physical activities in health promotion of aging people. Maturitas 58: 327-339. [Crossref]

105. Das S, Vasisht S, Das SN, Srivastava LM (2000) Correlation bewtween total antioxidant status and lipid peroxidation in hypercholesterolemia. Curr Sci 78: 486-487.

106. Brighenti F, Valtueña S, Pellegrini N, Ardigò D, Del Rio D, et al. (2005) Total plasma antioxidant capacity of the diet is inversely and independently related to plasma concentration of high-sensitivity C-reactive protein in adult Italian subjects. Brit J Nutr 93: 619-625.

107. Kwak HK, Yoon S (2007) Relation of serum total antioxidant status with metabolic syndrome risk factors in Korean adults. Nutr Res Pract 1: 335-340.

108. Niculescu L, Stancu C, Sima A, Toporan D, Simionescu M (2001) The total peroxyl radical trapping potential in serum: an assay to define the stage of atherosclerosis. $J$ Cell Mol Med 5: 285-294.

109. Demirbag R, Yilmaz R, Kunt AS, Gur M, Ulucay A, et al. (2006) Relationship between plasma total antioxidant capacity and thoracic aortic intima-media thickness. Echocardiography 23: 183-188. [Crossref]

110. Erel O (2004) A novel automated method to measure total antioxidant response against potent free radical reactions. Clin Biochem 37: 112-119. [Crossref]

111. Chien KL, Chen MF, Hsu HC, Chang WT, Su TC, et al. (2008) Plasma uric acid and the risk of type 2 diabetes in a Chinese community. Clin Chem 54: 310-316. [Crossref]
112. Hairong Nan, Zengchang Pang, Shaojie Wang, Weiguo Gao, Lei Zhang, et al. (2010) Serum uric acid, plasma glucose and diabetes. Diab Vasc Dis Res 7: 40-46. [Crossref]

113. Kashyap RR, Nair GR, Gogineni SB, Suchetha KN (2011) Salivary total antioxidant capacity in type 2 diabetes mellitus patients- a clinical and biochemical study amongst tobacco smokers. Int J Diabet Dev Ctries 31: 194-198.

114. Honorio-França AC, De Oliveira FC, França EL, Ferrari CKB (2015) Antioxidant and hypoglycemic effects of sulphurous water on alloxan-induced diabetic rats: a preliminary study. Nutr Clin Diet Hosp 35: 50-55.

115. Kumar KMP (2012) Antioxidants for clinical use. Int J Diab Dev Ctries 32: 183-184

116. Ghatak SB, Panchal SS (2012) Anti-diabetic activity of oryzanol and its relationship with the anti-oxidant property. Int J Diab Dev Ctries 32: 185-192.

117. De Oliveira VN, Bessa A, Jorge ML, Oliveira RJ, de Mello MT, et al. (2012) The effect of different training programs on antioxidant status, oxidative stress, and metabolic control in type 2 diabetes. Appl Physiol Nutr Metab 37: 334-344.

118. Gu Y, Lian X, Sun W, Gao B, Fu Y (2017) Diabetes mellitus induces alteration in metallothionein protein expression and metal levels in the testis and liver. $J$ Int Med Res.

119. Ferrari GSL, Ferrari CKB (2011) Exercise modulation of total antioxidant capacity (TAC): towards a molecular signature of healthy aging. Front Life Sci 5: 81-90.

120. Sari-Sarraf V, Amirsasan R, Zolfi HR (2016) Effects of aerobic and exhaustive exercise on salivary and serum total antioxidant capacity and lipid peroxidation indicators in sedentary men. J Kashan Univ Med Sci 20: 427-434.

121. Ferrari CKB, Percário S, Silva JCCB, Torres EAFS (2016) An apple plus Brazil nut a day keeps the doctors away: Antioxidant capacity of foods and their health benefits. Cur Pharm Des 22: 189-195.

122. El-Sabban F (2016) Quantification of dietary antioxidant capacity for better nutritional guidance. Nutr Food Toxicol 1: 1-2.

123. Martín J, Kuskoski EM, Navas MJ, Asuero AG (2017) Antioxidant capacity of anthocyanin pigments. In: Justino GC (Ed.). Flavonoids- From Biosynthesis to Human Health. InTech, Rijeka, Croatia. pp: 205-255.

Copyright: (C2017 Ferrari CKB. This is an open-access article distributed under the terms of the Creative Commons Attribution License, which permits unrestricted use, distribution, and reproduction in any medium, provided the original author and source are credited. 